\title{
Correction to: Parental care and reproductive behavior of the clown goby, Microgobius gulosus, with observations on predator interactions
}

\section{Ana Gaisiner}

Published online: 6 November 2020

(C) Springer Nature B.V. 2020

Correction to: Environmental Biology of Fishes (2005) 73: 341-356

https://doi.org/10.1007/s10641-004-6193-y

The original version of this article unfortunately contained a mistake.

The author's name is Ana Gaisiner, not Ana Gaisner.

The original article has been corrected.

Publisher's note Springer Nature remains neutral with regard to jurisdictional claims in published maps and institutional affiliations.

The online version of the original article can be found at https://doi.org/10.1007/s10641-004-6193-y

A. Gaisiner $(\bowtie)$

Department of Biology, The University of West Florida, Pensacola, FL 32514, USA

e-mail: agaisiner@gmail.com

Present Address:

A. Gaisiner

San Francisco, USA 